JISA: Jurnal Ilmiah Sosiologi Agama

Prodi Sosiologi Agama Fakultas IImu Sosial UIN SU Medan

Vol.1, No.2, Oktober Tahun 2018

\title{
TERORISME DAN ISLAM FUNDAMENTALISME
}

\section{Dr. Zulkarnain, MA}

\begin{abstract}
Abstrak
Terorisme adalah suatu tindakan yang dilakukan untuk meraih tujuan yang tidak manusiawi dan buruk (mufsid) dan mengancam segala macam jenis keamanan, dan pelanggaran atas hak azasi yang ditegaskan oleh agama atau manusia. Terorisme menyentuh beberapa aspek kehidupan manusia termasuk peradaban, politik, ekonomi, hingga agama. Akbar S. Ahmad menganalisis fundamentalisme sebagai sesuatu yang identik dengan golongan radikal (salah satu dari analisis segi tiga kesarjanaan Muslim), dan tampaknya pemikir postmodern ini menambah satu lagi ciri kaum fundamentalisme ini, yaitu vulgaritas, cenderung menggunakan kata-kata kotor dan kasar untuk menyudutkan lawan-lawan polemiknya, bahkan mereka sering kali tidak menyadari bahwa mereka telah membela kebenaran dengan cara kasar dan menjijikkan.
\end{abstract}

\section{Kata Kunci : Terorisme, Islam, Fundamentalisme}

\section{Pendahuluan}

Salah satu isu yang menggetarkan dunia dan kemanusiaan kontemporer adalah terorisme, karena isu ini telah menyentuh berbagai aspek kehidupan, mulai dari kemanusiaan, peradaban, politik, ekonomi, hingga kehidupan beragama. Terdapat sejumlah defenisi yang diberikan para ahli mengenai terorisme.

Isu ini menyentuh kemanusiaan karena ia telah menjadi momok bagi anak manusia, menimbulkan ketakutan, kebencian, tragedi kematian moral dan suara hati.

Menyentuh peradaban karena sering dikaitkan dengan peralihan kontroversi dunia dari perang dingin menjadi bentrok peradaban seperti hipotesis Samuel P. Huntington mengenai The Clash of Civilization.

Isu ini juga telah menyentuh persoalan politik karena menimbulkan kekacauan politik global, nasional, dan transnasional, masa kini dan mungkin juga di masa datang. 
JISA: Jurnal Ilmiah Sosiologi Agama

Prodi Sosiologi Agama Fakultas IImu Sosial UIN SU Medan

Vol.1, No.2, Oktober Tahun 2018

Para pengkaji dan peneliti masalah-masalah terorisme menyebutkan adanya kesulitan untuk mendefinisikan terorisme.Juliet Lodge ${ }^{12}$ misalnya menyebutkan adanya problem dalam mendefinikan isu dunia itu. Demikian juga halnya H. H. Tucker yang menyebutkan hal yang sama.

Dalam The Oxford Encyclopedia of the Modern Islamic World disebutkan bahwa terorisme adalah penggunaan kekerasan secara sengaja, tidak dapat dibenarkan, dan bersifat acak, demi tujuan-tujuan politik dengan sasaran orangorang yang dilindungi. Pelakunya bisa negara, agen negara, atau perorangan yang bertindak sendiri. ${ }^{3}$

Sementara dalam The Social Science Encyclopedia disebutkan bahwa terorisme adalah tindakan untuk menyebarkan intimidasi, kepanikan, dan kerusakan dalam masyarakat. Tindakan ini bisa dilakukan oleh individu, atau kelompok yang menetang sebuah negara, atau bertindak atas kepentingannya sendiri. ${ }^{4}$

Ayatullah Syaikh Muhammad Ali Taskhiri mengedepankan defenisi yang cukup penting mengenai terorisme, dan tinjauan yang diberikan tampak lebih fair dan religius.Menurutnya terorisme adalah suatu tindakan yang dilakukan untuk meraih tujuan yang tidak manusiawi dan buruk (mufsid) dan mengancam segala macam jenis keamanan, dan pelanggaran atas hak azasi yang ditegaskan oleh agama atau manusia. ${ }^{5}$

Lebih lanjut ia menyebutkan bahwa defenisi yang diberikannya tidak mencakup :

- Tindakan pembelaan negara yang menghadang kekuatan musuh, penjajah dan penjarah.

- Perlawanan rakyat atas trik-trik yang dipaksakan pada mereka oleh angkatan bersenjata.

- Penolakan atas kediktatoran dan berbagai bentuk kelaliman dan usaha untuk merusak lembaga-lembaganya.

- Perlawanan atas diskriminasi rasial dan penyerangan pada kubukubunya.

- Pembalasan pada berbagai jenis agresi bila tidak ada alternatif lainnya. ${ }^{6}$

\footnotetext{
${ }^{1}$ Juliet Lodge (Ed.), The Threat of Terrorism, (Boulder-Colorado: Westview Press, 1988), hlm. 1-10.

${ }^{3}$ August Richard Norton "Terrorism" dalam John L. Esposito (Ed.), The Oxford Encyclopedia of theModern Isalamic World, ( (New York: Oxford University Press, 1995), hlm. 205-209.

${ }^{4}$ Gianfranco Pasquino, "Terrorism" dalam Adam Kuper \& Jessica Kuper, (Ed.), The Social Science Encyclopedia, Machiavelli-World System.

${ }^{5}$ Ayatullah Seikh Muhammad Ali Taskhiri, The Defenition of Terrorism, dalam Al-Tawhid No.I/Vol. V, Muharram, 1408 H/1987. Dimuat dalam Al-Huda Volume I No.6, 2002.

${ }^{6}$ Ibid.
} 
JISA: Jurnal Ilmiah Sosiologi Agama

Prodi Sosiologi Agama Fakultas IImu Sosial UIN SU Medan

Vol.1, No.2, Oktober Tahun 2018

Dari berbagai defenisi yang dikemukakan para ahli dan peneliti tersebut, secara umum terdapat benang merah yang menghubungkan keseluruhan defenisi dan penjelasan mengenai terorisme, bahwa aksi terorisme menyangkut penggunaan serta ancaman kekerasan untuk menimbulkan ketakutan (the use of threat of violence to create fear); juga menculik dan membunuh (to kidnap and munder people); melemparkan bom (set off boms) menyandera kapal terbang (bijack aeroplanes) mengadakan pembakaran-pembakaran (start fires) dan melakukan kejahatan-kejahatan kriminal yang sangat serius dan kejam. ${ }^{7}$

Pada dasarnya terorisme adalah nafsu yang ingin memaksakan kehendaknya dengan kekerasan dan ancaman. Dilihat secara demikian maka terorisme adalah lawan demokrasi.Meskipun demikian, seperti disebut Gianfranco, terorisme sosio-politis dapat muncul di negara demokrasi dan non demokrasi. Tetapi sering muncul di negara demokratis karena atmosfir kebebasan lebih kondusif melahirkan kelompok-kelompok teroris. ${ }^{8}$

Banyak kutipan yang dapat dikedepankan sehubungan dengan tindakan teroris, dan sekaligus menjelaskan bahwa masalah terorisme adalah masalah yang sudah lama menjadi isu dunia.Sebagian di antara tindakan teroris itu adalah gerakan Ku Klux Klan, yang anti Negro, yang menggunakan teror dan pembunuhan. Demikian juga di zaman kediktatoran Hilter dan Mussolini, terorisme mereka untuk memberantas gerakan demokrasi. Di zaman Stalin, komunisme Uni Soviet menggunakan terorisme secara kejam dan tidak manusiawi.

Contoh nyata yang sekarang kita saksikan ialah terorisme Zionisme Israel terhadap rakyat Palestina khususnya, dan juga terhadap penduduk Arab sekitarnya. Bahkan yang sangat tragis dan ironis, seperti disebut Roeslan Abdulani, adalah bahwa terorisme Israel ini mendapat dukungan dan lindungan dari Amerika, yang selalu membanggakan diri sebagai negara demokrasi. ${ }^{9}$

Bila dilihat dari model gerakan dan aksi-aksinya, maka jenis utama terorisme dapat dibagi tiga: Terorisme revolusioner, terorisme sub-revolusioner, dan terorisme repressif, ${ }^{10}$ meskipun oleh Lodge kategori ini disebut sebagai overgeneralis karena tidak dijelaskan karakter masing-masing.

Akan tetapi kalau dilihat dari sudut pelaku dan cakupannya, maka terorisme dapat dikategorikan kepada terorisme internal dan terorisme internasional. Terorisme internal dilakukan oleh negara. Sementara terorisme internasional

\footnotetext{
${ }^{7}$ Roeslan Abdulgani, op.cit.

${ }^{8}$ Ibid.

${ }^{9}$ Roeslan Abdulgani, "Terorisme: Dulu dan Sekarang", pada Waspada, 25 Oktober 2002.

${ }^{10}$ Paul Wilkinson, "British Palicy on Terrorism : An Assessment" dalam Juliet Lodge (Ed.), The Threat of Terrorism, Colorado: Setview Press, 1988), hlm. 29-54.
} 
JISA: Jurnal Ilmiah Sosiologi Agama

Prodi Sosiologi Agama Fakultas IImu Sosial UIN SU Medan

Vol.1, No.2, Oktober Tahun 2018

adalah tindakan terorisme yang melewati batas satu negara terhadap siapa dan oleh siapa, atau siapa sponsornya.

Sementara itu apabila dilihat dari sudut subjeknya, tindakan terorisme bisa dilakukan oleh individu, kelompok, dan bisa pula dilakukan oleh negara. Apabila suatu negara terlibat sebagai pelaku terorisme, seperti disebut Ray S. Cline, maka defenisi kerja terorisme dapat dirumuskan sebagai :

Pemakaian kekerasan oleh negara dan kelompok yang berkaitan untuk mendapatkan tujuan strategis, politik atau agama, dengan tindakan kejahatan yang dimaksudkan untuk menciptakan kekhawatiran luas di populasi sasaran... Tujuan utama terorisme negara zaman sekarang ini adalah merusak stabilitas psiko-sosial dan pemerintah politik negara pluralis, dengan pemerintah refresentatif. ${ }^{11}$

Sedangkan kalau dianalisis dari sudut akibat serta dampak tindakannya, maka terorisme mungkin dilakukan dalam beberapa tingkat. Sebagaimana yang disimpulkan oleh Ali Taskhiri :

Ada terorisme yang mengganggu keamanan, harkat martabat, harta milik dan lain-lain. Ada terorisme budaya yang mencabik-cabik identitas kemanusiaan, dan menyebabkan kehancuran dan ketidakpastian; ada pula terorisme informasi yang merampas kebebasan manusia menghirup udara segar. Kita dapat menyebutkan jenis-jenis terorisme lain, seperti terorisme ekonomi, terorisme ilmiah, terorisme diplomatik, terorisme militer dan lainlain. ${ }^{12}$

Apabila kategori yang diberikan Taskhiri dijadikan sebagai pisau analisis maka tindakan-tindakan teror, atau terorisme, kelihatannya bukan lagi menjadi musuh dunia, tetapi juga menjadi budaya dunia. Sebab dalam tingkat tertentu hampir semua negara, terutama negara yang memiliki watak kolonialis telah dan sedang melakukannya.

\section{Terorisme, Media Informasi, dan Citra Palsu}

Terorisme dalam aksi-aksi dan tujuannya sangat erat kaitannya dengan media informasi. Dilihat secara demikian maka tujuan utama terorisme, bukanlah

${ }^{11}$ Ray S. Cline, Pengantar dalam H. H. Tucher (Ed), Combating The Terrorist: Democratic Respons to Political Violence, (New York: Fact on File, 1988), hlm. x. 
JISA: Jurnal Ilmiah Sosiologi Agama

Prodi Sosiologi Agama Fakultas IImu Sosial UIN SU Medan

Vol.1, No.2, Oktober Tahun 2018

kehancuran atau kematian itu sendiri, tetapi bagaimana kehancuran dan kematian itu menjadi sebuah "panggung tontonan" lewat media cetak, elektronika, atau digital yang diharapkan kian luas diseminasi medianya, maka akan semakin masal orang yang melihatnya, dan akan kian dahsyat pula efek ketakutan, kengerian, dan trauma yang ditimbulkannya.

Terorisme juga dapat berkembang menjadi pertukaran simbol (syimbolic exchange) atau perang simbol (symbolic war), yang di dalamnya ketakutan, kehancuran, dan kematian dijadikan sebagai pertanda (signifier), yang diharapkan memproduksi makna tertentu(signified), misalnya dengan adanya kasus Legian Bali, maka Indonesia diklaim sebagai sarang terorisme. Makna itu lalu dapat dipertukarkan dengan unsur lain (simbolik atau bukan), misalnya, akses investigasi atau militer negara tertentu ke wilayah teritorial seperti Indonesia. ${ }^{13}$

Lebih jauh, terorisme telah menjelma menjadi semacam "ideologisasi teror", dalam rangka menciptakan kategorisasi siapa yang teroris dan siapa bukan teroris.

Ideologisasi teror telah menciptakan apa yang disebut dengan "kesadaran palsu" (false consciousness) pada tingkat psikologi masyarakat global, melalui distorsi informasi besar-besaran tentang terorisme di dalamnya.

Pengalaman para penulis, serta opini-opini berbagai kalangan di berbagai media, koran, dan internet, menunjukkan Amerika Serikat adalah sebuah negara yang secara historis amat menguasai infrastruktur media global, dan sering menggunakannya untuk menciptakan distorsi informasi dan kesadaran palsu tentang terorisme. Bukan hanya itu, Chomsky menyebut Amerika Serikat sebagai "sang teroris yang berteriak teror"14

Idiologisasi teror oleh Amerika Serikat berlangsung dalam kerangka politik kekuasaan "politik imagologi" (imagology politics), politik penciptaan berbagai citra palsu atau "illusi", (illusion) tentang sebuah fenomena seperti terorisme, dalam rangka memperlihatkan superioritas demokrasi Amerika Serikat. Melalui mekanisme "pemaksaan secara halus" (symbolic violence).

Kalau demikian halnya, tampaknya pendapat Piliang dapat diterima bahwa fenomena terorisme global akan selamanya digiring kedalam semacam "citra cermin" (mirror image), yang mempatrikan kesadaran masyarakat global pada sebuah distorsi konotasi (distorted konnotation)tentang terorisme misalnya:

\footnotetext{
${ }^{13}$ Yasraf Amir Piliang, "Politikus Horrobilis, Hantu-Hantu Terorisme" dalam Kompas, 21 Oktober 2002.

${ }^{14}$ Noam Chomsky, Pirates and Emperor: Internastional Terrorism in the Real World, (1986) dan Hamid Mowlana, Riumph of the Image: The Media's War in the Persian Gulf, (1992) sebagaimana dikutip Piliang dalam op.cit.
} 
JISA: Jurnal Ilmiah Sosiologi Agama

Prodi Sosiologi Agama Fakultas IImu Sosial UIN SU Medan

Vol.1, No.2, Oktober Tahun 2018

Palestina, Iran, Irak, dan Korea Utara dengan terorisme, dan semoga jangan sampai termasuk Indonesia. ${ }^{15}$

Dalam kondisi demikian, dunia politik Internasional seperti dikatakan Walter Truett Anderson, ${ }^{16}$ akan tetap terkurung dalam sebuah "teater realitas" yang didalamnya bahan-bahan baku politik seperti peristiwa teror (yang boleh jadi sengaja diciptakan), dikemas apik dalam sebuah narasi dan pencitraan untuk kemudian diceritakan dan dipertontonkan di hadapan masyarakan global, dan kitapun -dengan percaya diri-- menyebutnya realitas teror.

\section{Terorisme dan Kejahatan Bermotif Kebencian}

Dalam tingkat tertentu terorisme juga dapat disebut sebagai kejahatan bermotif kebencian, atau setidak-tidaknya disulut oleh kejahatan bermotif kebencian, suatu fenomena yang saat ini sering muncul dalam kehidupan anak manusia, terutama dalam pergaulan antar kelompok.

Dalam terjadinya suatu kejahatan bermotif kebencian, pelaku dan korban tidak berdiri sebagai individu tetapi masing-masing mewakili kelompok yang terbentuk atas dasar kesamaan tertentu, perbuatan jahat yang dilakukan pelaku bersumber dari prasangka atau sikap penilaian negatif kelompoknya terhadap korban sebagai wakil kelompok lain yang menjadi sasaran kebencian.

Itulah sebabnya korban tindak kejahatan bermotif kebencian seringkali adalah orang-orang yang tidak bersalah, bahkan tidak tahu apa-apa, atau kesalahan karena kebetulan memiliki ciri atau bahkan kebetulan memiliki persinggungan dengan kelompok sasaran kebencian.

Kejahatan bermotif kebencian ini bisa muncul disebabkan beberapa faktor, di antaranya: Pertama, sekedar iseng atau sengaja mencari kesenangan sekaligus pamer kekuatan dan kekuasaan. Salah satu contoh sederhana adalah berbagai bentuk vandalisme yang dilakukan remaja kota besar atas rumah atau harta benda lain milik warga etnik minoritas, dan dalam skala lebih besar mungkin dapat dilihat dalam kejahatan suatu negara kepada negara lain yang lebih kecil dan lemah.

Kedua.Dengan dalih mempertahankan wilayah kekuasaan, kebencian penduduk asli terhadap warga pendatang baik yang memiliki kesamaan ras etnik

15 Dalam hal ini meng-image-kan Gerakan Aceh Merdeka dengan GAM menjadi memiliki keuntungan poilitik dan sekaligus kerugian. Keuntungan politik karena mungkin akan mendapat sokongan dunia sebagai upaya memerangi terorisme. Rugi karena boleh jadi akan menciptakan image bahwa Indonesia juga menjadi terkait dengan gerakan terorisme. Jika bukannya diklaim sebagai salah satu sarang teroris.

${ }^{16}$ Walter Truett Anderson, Reality Isn't What It Use to Be, (1990). 
JISA: Jurnal Ilmiah Sosiologi Agama

Prodi Sosiologi Agama Fakultas IImu Sosial UIN SU Medan

Vol.1, No.2, Oktober Tahun 2018

maupun yang berbeda ras etnik, dan termanifestasikan dalam kekerasan sehingga memicu kerusuhan.

Ketiga, dengan dalih melaksanakan misi suci untuk membasmi segala bentuk penyakit masyarakat.Berbagai tindakan sweeping swakarsa tanpa wewenang publik terhadap orang-orang atau tempat yang dianggap sebagai sarang kemaksiatan baik yang terorganisasi maupun spontan.

Keempat, dengan dalih melakukan retaliasi atau pembalasan. Hal tersebut bisa dilihat umpamanya dalam berlarut-larutnya konflik horizontal di tanah air, yang antara lain disebabkan oleh unsur lingkaran setan balas dendam. ${ }^{17}$

Faktor lain yang cukup signifikan dalam menyulut terjadinya tindakantindakan teror adalah ucapan yang bermotif kebencian, yang kian membudaya di tengah masyarakat. Sebab seringkali tindakan teror muncul akibat adanya ucapan dan istilah-istlah pejoratif, baik dalam skala kecil maupun yang bersakala besar.

\section{Islam Menolak Terorisme}

Adalah suatu kenyataan bahwa sehubungan dengan isu terorisme, umat Islam seringkali berada dalam posisi tersudutkan. Hal ini terjadi, selain disebabkan kekacauan dalam melihat Islam-- dalam arti normatif ajaran dengan Islam dalam arti sosiologis, prilaku orang yang menganut Islam-- juga karena nama Islam sering dicatut untuk tindakan-tindakan teror. Hal ini umpamanya terlihat pada bagaimana Islam dicatut dalam tindakan membom WTC, 11 September 2001 yang lalu, seperti terungkap dalam dialog Nehad Awad, Direktur Eksekutif Dewan Hubungan Islam Amerika dengan Mofid Deak, penulis Washington File berikut :

Deak:Apa pesan yang dikirimkan oleh kelompok anda dan kelompokkelompok Muslim Amerika setelah serangan tersebut.

Awad: Pesan yang kami kirimkan ialah bahwa kami adalah bagian dari proses penyembuhan nasional, dan bahwa komunitas kami sudah menderita ganda. Banyak anggota komunitas Muslim Amerika tewas atau luka dalam serangan tersebut, dan komunitas Muslim Amerika sudah dituduh atas tindakantindakan oleh oknum-oknum yang tidak kami kenal. Orang-orang tersebut bukan anggota komunitas kami di sini. Satu-satunya hal yang mereka ambil dari kami adalah nama agama kami, Mereka mencurinya dari kami, seperti halnya mereka mencuri nama dan identitas. Dan mereka secara keji menyamar

${ }^{17}$ Bandingkan A. Supratiknya, “Teror, Kejahatan Bermotif Kebencian?" dalam Kompas, 25 Oktober 2002. 
JISA: Jurnal Ilmiah Sosiologi Agama

Prodi Sosiologi Agama Fakultas IImu Sosial UIN SU Medan

Vol.1, No.2, Oktober Tahun 2018

nama-nama Islam, dan mereka melakukan kekejian.Itu saja yang mereka lakukan.

Para teroris itu adalah oknum-oknum yang sakit dan mereka tidak punya pengetahuan agama. Tidak ada hak bagi mereka atau siapapun untuk mengaitkan apa yang mereka lakukan dengan agama Islam. Pengetahuan mereka tentang agama dan praktek ajaran Islam sangatlah dangkal. ${ }^{18}$

Selain karena para teroris mengambil nama Islam, gambaran citra buruk mengenai Islam, khususnya umat Islam di Timur Tengah terus dihubungkan dengan terorisme. Bahkan Juliet Lodge secara eksplisit mengemukakan tanggapan Capitanchik yang menggunakan kata "IslamicTerrorism", yang meskipun menggunakan tanda petik tetapi nuansa menyudutkan Islam tetap terlihat kentara.

Pada sisi lain Richard Norton menulis:

Lebih dari bagian manapun dari umat Islam, Timur Tengah, sejak Perang Dunia Kedua, memiliki reputasi buruk sebagai ajang terorisme kendati banyak pelakunya tidak mengaku bertindak atas nama Islam. ${ }^{19}$

Bernard Lewis mengemukakan kalimat yang lebih eksplisit ketika ia mengatakan:

Sebagian besar umat Islam bukanlah fundamentalis dan sebagian besar fundamentalis bukanlah teroris. Namun sebagian besar teroris adalah muslim dan mereka dengan bangga mengakui diri mereka sebagai muslim. Dapat dipahami kalau kaum muslimin protes ketika media mengatakan bahwa gerakan dan perbuatan teroris sebagai gerakan dan perbuatan Islam... Namun sebagaimana Hitler dan Nazi yang muncul dari kalangan umat Kristen, mereka juga harus dipandang dalam konteks budaya, aga,a, dan sejarah mereka sendiri. ${ }^{20}$

Namun perlu disadari bahwa Islam sama sekali menolak tindakan-tindakan teror, apalagi terorisme. Dari makna generiknya saja kedua istilah itu bertolak belakang. Kalau terorisme memiliki muatan ancaman kekerasan yang menimbulkan ketakutan, pembunuhan, dan bahkan kebencian, maka Islam

\footnotetext{
${ }^{18} \mathrm{http} /$ unsembassy.state.gov/jakarta/wwwhcir.html.13/07/2003, hlm.3-4

${ }^{19}$ Richard Norton, op.cit.

${ }^{20}$ Bernard Lewis, The Crisis of Islam: Holy War and Unholy Terror, (Rondom House, Inc., Co., Ltd, 2003)
} 
JISA: Jurnal Ilmiah Sosiologi Agama

Prodi Sosiologi Agama Fakultas IImu Sosial UIN SU Medan

Vol.1, No.2, Oktober Tahun 2018

bermakna keselamatan, penyerahan diri kepada Tuhan, kecintaan kepada Tuhan berarti kecintaan pada sesama, dan dambaan terhadap situasi masyarakat yang tanpa kekacauan.

Dalam perpsektif ini memang sangat tidak layak jika Islam disudutkan dengan alasan prilaku kekerasan, termasuk image kekerasan dalam penyebarannya, sehingga Islam diimagekan sebagai "agama pedang”. Dalam hal ini menarik sekali komentar Osman Bakar:

Tidak bisa dipungkiri di beberapa wilayah, kekuatan pedang memiliki peran dalam ekspansi teritorial Islam. Tetapi jika ini saja dianggap cukup untuk mencirikan Islam sebagai "agama pedang" maka karakteristik serupa bisa diberlakukan terhadap agama Kristen atau Budhisme, karena kedua agama tersebut sesungguhnya melakukan peperangan baik dalam upaya mempertahankan atau ekspansi teritorial.

Namun jika yang dimaksud dengan "agama pedang" itu berarti bahwa agama pada dasarnya disebarkan melalui konvensi yang dipaksakan, maka hal ini lebih tepat bila dilekatkan pada agama Kristen dari pada Islam. ${ }^{21}$

Suatu kajian yang sederahana sekalipun terhadap Islam akan menemukan informasi yang melimpah ruah mengenai penolakan terhadap tindakan-tindakan teror. Islam memiliki pendapat mengenai Al- baghyi, pemberontakan bersenjata menentang pemerintahan yang sah dan adil, intimidasi kepada rakyat, penyelidikan politik dengan tujuan memecah belah, dan membahayakan keutuhan nasional. Islam juga memiliki pendapat mengenai penggunaan senjata untuk mengintimidasi rakyat sebagaimana firman Allah Swt:

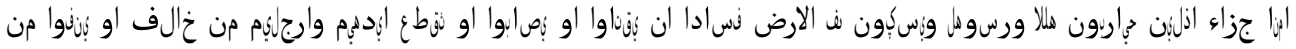

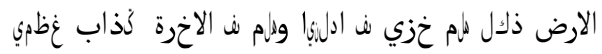

Hukuman bagi orang-orang yang memerangi Allah dan Rasul-Nya dan membuat kerusakan di bumi, hanyalah dibunuh atau disalib atau dipotong tangan dan kaki mereka secara silang atau diasingkan dari tempat kediamannya.Yang demikian itu kehinaan bagi mereka di dunia dan di akhirat mereka mendapat azab yang besar.(Q.S. 5/al-Mâidah:33).

\footnotetext{
${ }^{52}$ Osaman Bakar, Islam and Civilizational Dialogue, (Kuala Lumpur: Universitas Malaya Press, 1977), hlm. 38 .
} 
JISA: Jurnal Ilmiah Sosiologi Agama

Prodi Sosiologi Agama Fakultas IImu Sosial UIN SU Medan

Vol.1, No.2, Oktober Tahun 2018

Selain itu terdapat juga teks-teks yang menetapkan penghormatan dan kesetiaan yang tinggi terhadap perjanjian, dan lain-lain.

Tampaknya inilah yang melatar belakangi tokoh-tokoh Islam menegaskan kembali sikap Islam itu, segera setelah peristiwa peledakan WTC. Yusuf alQardawi, misalnya dalam Islam On line \& News Agencies menyebutkan: "Islam adalah agama yang toleran yang menempatkan jiwa manusia dalam rasa hormat yang tinggi dan menganggap serangan terhadap orang yang tidak bersalah sebagai dosa yang sangat besar."22

Dengan begitu Islam membuktikan sendiri penolakannya terhadap tindakantindakan teror.Sehingga tidak adil kalau Islam sebagai agama dan umatnya disudutkan dalam isu global terorisme.

Pada saat yang sama Islam juga menegakkan kejujuran, sehingga kedustaan merupakan dosa. Sikap anti kekerasan dalam menimbulkan ketakutan tersebut telah didaratkan nabi Muhammad SAW dan para sahabat yang arif bijaksana dalam kehidupan mereka, yang menjadi suri tauladan bagi segenap umat Islam.

Dalam memberikan komentar terhadap Surat 3/Ali Imrân ayat 159, Abdullah Yusuf Ali mengatakan:

Karena sifat Muhammad yang begitu lemah lembut, menyebabkan semua orang sayang kepadanya, dan inilah salah satu rahmat Allah.Salah satu gelar Rasulullah ialah "rahmat untuk alam semesta".Sesudah peristiwa Uhud tak pernah ada yang lebih berharga baginya dari pada sifatnya yang begitu lemah lembut, penuh kasih sayang dan kesabaran yang begitu besar menghadapi kelemahan manusia.Ini adalah sifat yang sungguh agung, yang kemudian dan selalu demikian menyebabkan banyak sekali orang yang tertarik kepadanya. ${ }^{23}$

Para ahli, baik Muslim maupun non Muslim (akan Muslim) sangat mengerti bahwa Islam menentang terorisme. Dalam The Oxford Encyclopedia of the Modern Islamic World disebutkan bahwa :"Jelas tindakan terorisme tidak ada hubungannya sama sekali dengan Islam atau agama besar manapun". 24

\section{Islam dan Fundamentalism}

\footnotetext{
${ }^{22}$ Yusuf al-Qardhawi, Islam on line \& News Agencies, 13 September 2001.Dimuat dalam, Departemen luar negeri Amerika serikat, Jaringan Teroris, 2001.

23 Abdullah Yusuf Ali, The Holy Qur'an: Text Translation and Commentary, (USA: Amana Corporation, 1989), komentar 471.

${ }^{24}$ John L. Esposito, op.cit.
} 
JISA: Jurnal Ilmiah Sosiologi Agama

Prodi Sosiologi Agama Fakultas IImu Sosial UIN SU Medan

Vol.1, No.2, Oktober Tahun 2018

Praktis hampir semua kaum muslim mengakui bahwa ajaran Islam bersumber kepada Al-Qur'ân dan Al-Hadîs, dua sumber yang bersifat transenden, mengatasi ruang dan waktu.

Namun, sebuah telaah terhadap Islam tentu tidak bisa hanya memahami kedua sumber yang transenden itu, sebab sebuah ajaran senantiasa mengalami proses aktualisasi ke dalam realitas sosial para penganutnya. Aktualisasi doktrin ke dalam realitas sosial penganutnya itulah yang disebut dengan corak keberagamaan kaum muslimin.

Corak keberagamaan senantiasa dipengaruhi oleh dua faktor. pertama, faktor internal yang meliputi kecenderungan corak pemahaman dan penafsiran terhadap doktrin agama bersangkutan. Kedua, faktor eksternal, yang meliputi keterlibatan sejarah, etnik, budaya, dan faktor-faktor politik.

Sepanjang sejarah Islam telah muncul corak beragama yang tidak terbilang banyaknya, bahkan nyaris sejumlah kelompok yang menganut agama itu. Mulai dari kelompok yang menekankan aspek legal formal yang dikembangkan para fuqahâ', kelompok yang menekankan aspek spiritualitas, sampai pada kecenderungan tradisionalisme dan modernisme, ${ }^{1}$ yang muncul abad ini. Dan yang menarik dari kemunculan corak beragama tersebut adalah, seringkali kemunculan yang satu merupakan alternatif, jika bukannya merupakan caunter bagi yang lain.

\section{Fundamentalisme, Apa Maksudnya?}

Pada penggalan akhir abad ke 20 ini kita dapat menyaksikan munculnya sebuah corak keberagamaan 'baru' di kalangan umat beragama yang lazim disebut dengan istilah 'fundamentalisme'. Suatu istilah yang bukan berasal dari terminologi Islam, sebagaimana juga tradisionalisme dan modernisme, tetapi berasal dari bahasa Inggris yang lahir dalam konteks sejarah keagamaan di dunia kristen Amerika Serikat. ${ }^{25}$

\footnotetext{
${ }^{1}$ Paling tidak ada dua ciri yang secara amat menonjol ditunjukkan oleh kaum trasisional. Pertama, kecenderungan untuk memahami doktrin dengan merujuk kepada warisan tradisi abad pertengahan. Kedua, semangat akomodatif yang tinggi terhadap tradisi setempat yang telah mapan. Kedua ciri ini seringkali berimplikasi pada sikap enggan membuka wawasan baru bagi penafsiran ulang terhadap doktrin dalam menghadapi tantangan zaman yang senantiasa berubah.

Dalam keadaan demikianlah modernisme muncul sebagai reaksi terhadap tradisionalisme ini. Moderenisasi bertitik tolak dari pandangan universalisme Islam dan adanya dinamika perubahan yang terus menerus terjadi dalam sejarah, sehingga doktrin yang universal harus di tafsirkan ulang dengan mempertimbangkan faktor-faktor sosial yang terdapat di tengah masyarakat.

${ }^{25}$ Dewasa ini penganut istilah fundamentalisme memang telah mengalami kesimpangsiuran makna, dan bahkan cenderung menjadi istilah yang bias (berat sebelah) dan pejorative (bersifat merendahkan), bahkan seringkali digunakan dengan konotasi negatif. Hlm ini disebabkan selain karena
} 
JISA: Jurnal Ilmiah Sosiologi Agama

Prodi Sosiologi Agama Fakultas IImu Sosial UIN SU Medan

Vol.1, No.2, Oktober Tahun 2018

Ada dua ciri yang amat menonjol, yang seringkali secara amat menonjol ditampakkan kaum fundamentalisme (Khususnya di kalangan kaum fundamentalisme kristen Amerika Serikat), yaitu Pertama, cenderung menafsirkan teks-teks keagamaan secara rigid (kaku) dan literalis (harfiah). ${ }^{26}$ Dua ciri ini seringkali berimplikasi pada sikap mereka yang radikal, militan, berpikir sempit, (narrow minded), bersemangat secara berlebih-lebihan (ultra-zealous) atau cenderung ingin mencapai tujuan dengan memakai cara-cara kekerasan. ${ }^{27}$

Akbar S. Ahmad menganalisis fundamentalisme sebagai sesuatu yang identik dengan golongan radikal (salah satu dari analisis segi tiga kesarjanaan Muslim), dan tampaknya pemikir postmodern ini menambah satu lagi ciri kaum fundamentalisme ini, yaitu vulgaritas, cenderung menggunakan kata-kata kotor dan kasar untuk menyudutkan lawan-lawan polemiknya, bahkan mereka sering kali tidak menyadari bahwa mereka telah membela kebenaran dengan cara kasar dan menjijikkan.28

Kecenderungan menafsirkan teks-teks keagamaan secara rigid dan literalis itu ternyata tidak hanya ditemukan di dunia Kristen Protestan, tetapi juga ditemukan pada penganut agama-agama lain. Itulah sebabnya para orientalis Islamicist Barat kemudian menyebut kecenderungan serupa itu dikalangan

ia muncul dalam dunia Kristen yang kemudian digunakan pada gejala yang sama pada semua agama, juga karena latar belakang munculnya sendiri: (1) fundamentalisme lahir dalam situasi komflik antara budaya urban dan budaya pedesaan dalam sejarah kebudayaan Amerika Serikat pada pasca perang dunia I, yang muncul bersama dengan situasi depresi nilai-nilai agraris dalam proses industrialisasi dan urbanisasi di negeri itu. Bentuknya yang agresif sering muncul di daerah-daerah terisolisasi dan hanya sedikit saja yang terdapat simpati dari kalangan kota, (2) fundamentalisme merupakan gerakan reaksi terhadap pola peradaban yang timbul dari proses industrialisasi dan urbanisasi. Jadi fundamentalisme muncul untuk menentang modernisme yang menerima perubahan sosial sebagai hukum sosial yang tidak terhindarkan, (3) aliran fundamentalisme melawan arus pemikiran ilmiah yang mendasarkan diri pada penalaran dan arus sekularisme.

Aliran fundamentalisme mendasarkan diri pada faham supernaturalisme konservatif yang melahirkan doktrin lima butir fundamentalisme, yang merupakan program dasar kebenaran/keimanan (a Testomony of the truth). Yaitu (1) kebenaran mutlak dan tiadanya kesalahan pada kitab Injil (Holy Bible), (2) kelahiran Yesus dari Ibu Maria yang suci, (3) penebusan dosa untuk umat manusia oleh Yesus, (4) kebangkitan kembali Yesus secara jasmani yang turun ke bumi, 5) ketuhanan Yesus Kristus. Lihat George W. Dolar, A Histori of fundamentalism in America, (Greenville: Bon John University, 1973). Lihat pula Soetarman SP at al, Fundamentalisme,Agama-agama dan Tehnologi, (Jakarta: BPK Gunung Mulia, 1992). Lihat pula dalam Dawam Raharjo, Fundamentalisme, dalam KKA 74/Tahun VII 1993.

${ }^{26}$ Yusril Ihza Mahendra, Fundamentalisme Sebagai Corak Keagamaan, (KKA 74/Tahun VII/1993) hlm 171

${ }^{27}$ Lihat Dawam Raharjo, op, cit, hlm 2.

${ }^{28}$ Akbar S. Ahmed, Postmodernisme and Islam: Predicement and Promise, diterjemahkan ke bahasa Indonesia Posmodernisme: Bahaya dan Harapan bagi Islam, (Bandung: Mizan, 1993) hlm. 171. 
JISA: Jurnal Ilmiah Sosiologi Agama

Prodi Sosiologi Agama Fakultas IImu Sosial UIN SU Medan

Vol.1, No.2, Oktober Tahun 2018

masyarakat Muslim sebagai Fundamentalis Muslim, ${ }^{29}$ Klaim ini jelas sangat skematis dan merepotkan..$^{30}$ Penamaan serupa juga diberikan kapada penganut agama lain semisal fundamentalisme Yahudi, fundamentalisme Hindu, fundamentalisme Sikh, dan lain-lain. Bahkan media massa barat menggunakan istilah fundamentalisme terhadap semua gerakan yang cenderung menggunakan kekerasan dalam mencapai tujuannya, seperti yang terlihat pada kelompokkelompok politik Palestina, Aljazair, Iran, Mesir, Afganistan, dan lain-lain.

Pembicaraan fundamentalisme bila dihubungkan dengan Islam memang sangat merepotkan, sebab term tersebut sebaiknya tidak dapat digunakan terhadap corak keberagamaan macam apapun dalam agama itu. Bahkan berbagai diskusi di kalangan umat Islam telah menolak penggunaan istilah yang bias dan pejoratif itu.

Namun sebagai komunitas yang hidup di dunia yang semakin mengglobal ini, kita harus dapat lebih opensif terhadap berbagai peristilahan yang dimunculkan oleh barat khususnya Amerika sebagai negara super power saat ini. Sebab, sekali istilah itu dipopulerkan oleh negara itu, segerak akan menjadi istilah dunia, dan kita pun tidak mungkin mencegah dunia untuk tidak menggunakanya, bahkan seperti di sebut Bernald Lewis, seorang ahli sejarah Islam, 'penggunaan istilah itu sudah mapan dan dapat diterima'. ${ }^{31}$

Oleh karenanya, yang segera harus kita lakukan adalah melakukan telaahan terhadap fundamentalisme yang bebas dari sikap pejoratif dan bias,

${ }^{29}$ Muamar Qadafi dari Libya dan Khomeini dari Iran seringkali disebut sebagai tokoh fundamentalisme Muslim itu. Namun, klaim tersebut memang harus dikaji lebih dalam lagi sebab dua tokoh itu sukar disebut sebagai tokoh fundamentalis mengingat pokok-pokok pikiran tokoh yang disebut pertama merumuskan Islam dengan kerangka analisis marxisme, Bahkan ia sendiri menamakan

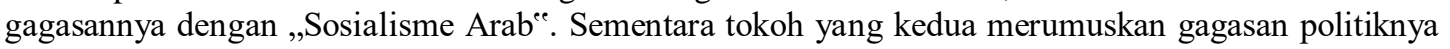
dengan corak khas pemikiran Syieah. Lihat Muamar Qadafi, Green Books, (Tropoli, 1979). Lihat pula James S. Piscatoriy, Islam in the Political Process, (Cambridge: Cambridge University Press, 1983), hlm. 160-180.

${ }^{30}$ Disebut skematis, karena istilah yang muncul dari dunia Kristen itu tidak cocok digunakan untuk dunia Islam. Jadi khusus kasus kristen. Hlm ini bisa dilihat dari defenisi fundamentalisme itu sendiri yang diberikan Encyclopedia of the Social Science (1968), Sebagai sebuah nama tentang gerakan agresif dan konservatif di lingkungan gereja Kristen Protestan di Amerika Serikat yang berkembang dalam desawarsa setelah perang Dunia I. Gerakan ini tercetus terutama di lingkungan gereja-gereja Baptis, Desciple, dan pressbyterian dan mendapat dukungan dari sebagian kalangan pendeta.

Disebut merepotkan, sebab Islam memiliki ajaran yang sangat fundamentalis yaitu rukun Islam dan rukun Iman, sehingga secara harfiah orang yang berpegang teguh kapada ajaran fundamental tersebut dapat disebut fundamentalis, itulah sebenarnya banyak sarjana (Muslim dan non Muslim) berkeyakinan bahwa istilah itu hanya cocok digunakan untuk kalangan Kristen Protestan.

${ }^{31}$ Lihat Dawan Raharjo, op. cit, hlm 2 
JISA: Jurnal Ilmiah Sosiologi Agama

Prodi Sosiologi Agama Fakultas IImu Sosial UIN SU Medan

Vol.1, No.2, Oktober Tahun 2018

agar meskipun ada yang ingin menancapkan istilah itu kedunia Islam menjadi tidak 'nyasar'.

Untuk itu perlu kita kenali ciri-ciri utama yang menjadi landasan pandangan fundamentalisme dan menganalisis implikasinya pada pendirian dan gerakan mereka. Untuk mempertajam analisis kita, secara kategoris kita akan membedakanya dengan corak keberagamaan lain, terutama dengan kaum modernis.

Seperti disebut di muka bahwa ciri utama fundamentalisme adalah interpretasi mereka yang rigid dan literalis terhadap doktrin agama. Ini dilatarbelakangi oleh beberapa faktor diantaranya (1) penafsiran seperti itu penting menurut mereka demi menjaga kemurnian dokrin dan pelaksanaannya, (2) diyakini bahwa penerapan doktrin secara utuh (kaffah) merupakan satusatunya cara dalam menyelamatkan manusia dari kehancuran.

Penafsiran rigid dan literalis tersebutakan terlihat paling tidak dalam tiga hal. Pertama, memandang cakupan doktrin agama, kedua, kedudukan sistem pemerintahan yang di selenggarakan Nabi Muhammad SAW, ketiga, dalam memandang kemajemukan masyarakat.

\section{Sikap memandang cakupan doktrin keagamaan}

Kaum funmentalisme dan modernis sama-sama berkeyakinan bahwa doktrin agama sebagaimana yang terdapat dalam al-Qur'ân dan Hadîs adalah doktrin yang universal, mencakup segala aspek dalam kehidupan manusia. Namun keduanya berbeda dalam menginterpretasikan universalistik Islam dan arti mencakup segala aspek kehidupan manusia. ${ }^{32}$

Bagi kaum modernis universalitas itu adalah prinsip-prinsip umum yang disimpulkan melalui perenungan intelektual (ijtihad) terhadap doktrin serta kajian ilmiah terhadap kehidupan sosial masyarakat di dunia ini. Adapun perinciannya dapat diserahkan kepada pertimbangan rasional sesuai dengan keadaan masa.

Metode berfikir seperti ini memang sangat sukar diterima oleh kaum fundamentalis, sebab bisa berimplikasi pada pengadopsian sistem yang di produksi Barat, untuk kajian-kajian dan bahkan konstitusi-konstitusi keislaman. Oleh sebab itu kaum fundamentalis memandang kaum modernis sebagai pihak yang paling bertanggung jawab terhadap terjadinya sekularisasi di dunia Islam karena pengaruh Barat, seperti dilukiskan Fazlur Rahman.

Fundamentalisme posmodernis sekarang, dalam skala penting, adalah baru, karena aktusiasme dasarnya adalah anti Barat - isyu kesukaan

${ }^{32}$ Bruce Lawrence, Defenders, of God:The Fundamentalist Revolt Against the Modern Age, (New York: I.B. Tauris, 1990), hlm 40. 
JISA: Jurnal Ilmiah Sosiologi Agama

Prodi Sosiologi Agama Fakultas IImu Sosial UIN SU Medan

Vol.1, No.2, Oktober Tahun 2018

neofundamentalis adalah larangan atas bunga bank, larangan atas keluarga berencana, kedudukan wanita, pengumpulan zakat, dan seterusnya hal-hal yang membedakan Islam dengan Barat. Sementara kaum modernis terkait dengan Barat. 33

Dalam memandang cakupan doktrin itu, kaum fundamentalis menafsirkan bahwa seluruh doktrin adalah universal dan berlaku tanpa dibatasi ruang dan waktu. Proses intelektualisasi menjadi tidak penting. Fundametalis lebih menekankan ketaatan dan kesediaan menundukkan diri kepada kehendak Tuhan, dan bukan perbincangan intelektual. Oleh karenanya seringkali kaum fundamentalis berhujjah bahwa yang lebih penting bagi mereka adalah 'Iman' bukan 'diskusi'. Iman justru membuat orang mengerti dan bukan mengerti yang membuat orang menjadi beriman.

Rasionalitas menurut kaum fundamentalis pada umumnya cenderung hanya menjadi alat untuk meligitimasi keinginan nafsu dalam mempermudah agama. Menurut mereka yang paling penting adalah memelihara sikap 'militan' dalam menegakkan agama, dan bukan memelihara semangat intelektualisme yang cenderung membuat orang tidak berbuat apa-apa. ${ }^{34}$

\section{Kedudukan sistem pemerintahan yang diselenggarakan Nabi Muhammad}

Kedua kelompok ini (fundamentalis dan modernis) sama-sama punya keinginan untuk melakukan idealilisasi terhadap zaman awal Islam, pada masa Rasul dan para Khalifah nan saleh (al-salaf al-shaleh), namun menempuh cara yang berbeda. Kaum modernis menekankan bahwa yang harus ditiru dari zaman awal itu adalah prinsip-prinsipnya yang universal, struktur pemerintahan pada masa Nabi dan Khalifah al-Rasyidun tidak perlu dijelmakan kembali dalam bentuk aslinya, tetapi hanya prinsip-prinsipnya, seperti tanggung jawab, musyawarah, keadilan, dan sebagainya. Sementara aplikasinya dapat direkayasa menurut kondisi zaman yang bersangkutan. Berbeda dengan itu kaum fundamentalis secara rigid ingin menegakkan pemerintahan zaman Nabi dan khalifah al-rasyidun itu sebab dipandang sebagai sesuatu yang berlaku untuk semua zaman dan kondisi.

Begitulah, kaum modernis tidak memandang penting menegakkan simbolsimbol yang bercorak distinktif, akan tetapi senantiasa memikirkan bagaimana caranya agar prinsip-prinsip Islam dapat menjiwai kehidupan masyarakat dan negara. Kaum fundamentalis sebaliknya, ingin menegakkan simbol-simbol itu, sebab mereka menganggap Islam adalah sebuah sistem yang lengkap dan

${ }^{33}$ Fazluh Rahman, Islam and Modernity: Transformational of an Intellectual Tradition, (Chicago: The University of Chicago Press, 1984), hlm 136.

${ }^{34}$ Dilaporkan Yusril Ihza, dalam op.cit, hlm 15 
JISA: Jurnal Ilmiah Sosiologi Agama

Prodi Sosiologi Agama Fakultas IImu Sosial UIN SU Medan

Vol.1, No.2, Oktober Tahun 2018

mencakup berbagai sistem di dalamnya, ada sistem ekonomi dan sistem politik, ada sistem pendidikan, dan sebagainya. 35

\section{Sikap memandang kemajemukan masyarakat}

Kaum fundamentalis cenderung bersifat negatif terhadap kemajemukan masyarakat. Mereka membedakan secara tegas dua jenis masyarakat; masyarakat Islam dengan masyarakat jahiliah. Perbedaan antara keduanya jelas, yang satu haq dan yang lain bathil. Sementara Al-Qur'ân melarang untuk mencampuradukkan antara kaduanya. Dengan demikian mereka sangat tertutup terhadap sumbangan peradaban lain, sungguhpun tidak selamanya dilaksanakan secara konsisten. Kebaikan tidak perlu diambil dari masyarakat jahiliah yang bercorak 'kafir' dan taghut itu. Kaum fundamentalis sangat terbiasa dengan katakata menjalankan Islam secara kaffah, dan untuk itu keadaan masyarakat selalu harus dikembalikan seperti zaman Nabi dan para sahabat.

Analisis di atas memperlihatkan bahwa fundamentalisme muncul serangkai disebabkan sikap oposisi dan kecemburuan sosial, dan tidak membangun suatu karangka intelektual yang canggih seperti yang dilakukan oleh kaum modernis atau neomodernis. Oleh karenanya fundamentalisme akan tumbuh subur di tengah-tengah masyarakat yang kondusif untuk perkembangnnya yaitu adanya penguasa yang tidak begitu peduli pada keadaan sosial, dan ditengah masyarakat yang tidak berkembang ilmiah.

\section{Islam Rahmatan Lil 'Âlamîn (Is-RA)}

Sejak diturunkan melaui insan pilihan, Rasulullah Muhammad SAW Islam telah menjadi pelipur lara bagi seluruh umat manusia. Dunia dan seisinya di transfer dari kegelapan (al-zhulumât) kesuasana yang terang benderang (al-nûr).

Dalam salah satu hadis, Rasulullah menegaskan:

$$
\text { الن بند و اجحد واليقني وادارش ويبي الدئوبة }
$$

Aku Muhammad dan Ahmad (terpuji), yang dihormati, yang ,menghimpun manusia, nabi (penyeru) taubat dan nabi (penyebar) rahmat (kasih saying). (HR. Muslim).

Kekuasaan yang semena-mena dihentikan Islam dengan menawarkan kepemimpinan yang berkasih sayang.Kebiasaan saling mengancam dan menakuti

\footnotetext{
${ }^{35}$ Lihat misalnya, Abdul A 'la al-Maududi, Mu'asiyat al-Islam,(Lahore: Pan Islamic
} 
JISA: Jurnal Ilmiah Sosiologi Agama Prodi Sosiologi Agama Fakultas IImu Sosial UIN SU Medan

Vol.1, No.2, Oktober Tahun 2018

Publisher, 1981), Lihat pula Sayyid Qutb, Ma'âllim fi al-Târikh, (Kuwait: Lifso, 1976). 
JISA: Jurnal Ilmiah Sosiologi Agama

Prodi Sosiologi Agama Fakultas IImu Sosial UIN SU Medan

Vol.1, No.2, Oktober Tahun 2018

dirombak menjadi hubungan antar personal dan antar kelompok yang saling menyayangi. Sabda Rasulullah Saw:

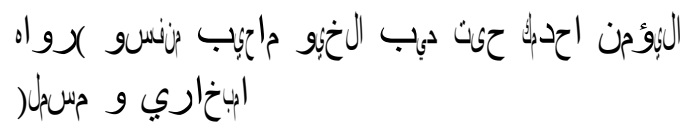

Seseorang belum pantas disebut beriman kalau dia tidak sayang pada yang lain sebagaimana ia menyayangi diri sendiri. (HR. Bukhâri dan Muslim).

Islam datang membawa rahmat bagi seluruh alam (rahmatan li al'âlamin).Kasih sayang tidak saja terhadap kekasih, keluarga, dan kaum kerabat.Akan tetapi kasih sayang diberikan kepada semua makhluk.Dalam sebuah hadis qudsi disebutkan :

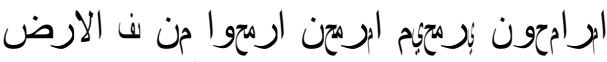

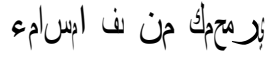

Mereka yang saling menyayangi akan disayang oleh pemilik kasih saying. Sayangilah yang ada di bumi nisacaya yang dilangit menyayangimu.

Kasih sayang yang ditawarkan Islam sangat sistematis dan konprehenship. Allah Swt., tidak saja menjadikan kasih sayang sebagai salah satu tema penting AlQur'an, tetapi semua surat dalam kitab suci ini dimulai dengan kalimat pembuka (iftitah) yang menegaskan kasih sayang (bismillâh al-rahmân al-rahîm), dengan menyebut nama Allah yang Maha Pengasih lagi Maha Penyayang (Q.S. 1/al-Fâtihah $: 1)$.

Tawaran kasih sayag Islam tidak saja dibicarakan dalam konteks intra kelompok dan komunitas. Sebab Allah meminta agar setiap orang muslim tidak boleh marah kepada orang lain yang tak sepaham dan bahkan tak seagama dengan mereka.

Menjadikan manusia tidak satu agama atau tidak sepaham merupakan kenyataan yang tidak dapat dipungkiri, Allah berfirman : dan jika Tuhanmu menghendaki tentulah akan beriman orang yang ada di muka bumi seluruhnya. Firman Allah Swt:

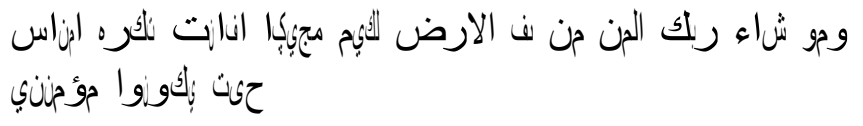


JISA: Jurnal Ilmiah Sosiologi Agama Prodi Sosiologi Agama Fakultas IImu Sosial UIN SU Medan Vol.1, No.2, Oktober Tahun 2018

Dan jika Tuhanmu menghendaki tentulah beriman semua orang dibumi seluruhnya.Tetapi apakah kamu (hendak) memaksa manusia agar mereka amenjadi orang-orang yang beriman?(Q.S. 10/Yûnus:99). 
JISA: Jurnal Ilmiah Sosiologi Agama

Prodi Sosiologi Agama Fakultas IImu Sosial UIN SU Medan

Vol.1, No.2, Oktober Tahun 2018

Mengomentari ayat ini Abdullah Yusuf Ali, seorang musafir modern menyatakan : orang yang beriman tidak boleh marah jika berhadapan dengan orang yang tidak beriman, dan terutama ia harus dapat menahan diri dari godaan kekerasan, misalnya memaksakan iman kepada orang lain, semisal tekanan sosial, politik, dan ekonomi membujuk dengan harta atau kedudukan atau mengambil manfaat cara lain yang dibuat-buat. Iman yang dipaksakan bukanlah iman, mereka harus berusaha dengan jalan rohani dan barulah Tuhan yang memberi hidayah$\mathrm{Nya}^{36}$.

Ayat dan penafsir ini menjelaskan bahwa Islam tidak diperkenankan melakukan kekerasan, menakut-nakuti, meledakkan bom untuk membunuh manusia lain. Sebab dalam perspektif agama Islam "orang yang membunuh seorang manusia berarti ia telah membunuh manusia secara keseluruhan. Firman Allah Swt:

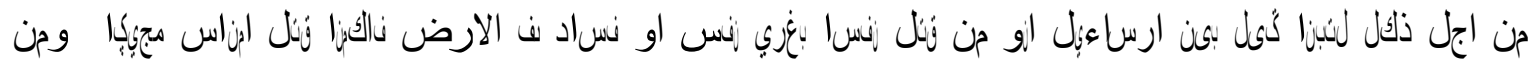

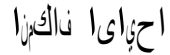

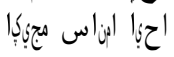

Karena itu kami tentukan kepada Bani Israil: Bahwa barang siapa membunuh orang yang tidak membunuh orang lain atau membuat kerusakan di bumi maka ia seolah-olah membunuh semua orang, dan barang siapa amenyelamatkan nyawa orang maka ia seolah mehyelamatkan nyawa semua orang. (Q.S.5/al-Mâ'idah: 32).

Mengomentari ayat ini Abdullah Yusuf Ali mengaamatakan:

Membunuh atau merencanakan pembunuhan pribadi orang karena pribadi tersebut mewakili suiatu gagasan, samalah dengan membunuh siapa saja yang mendukung gagagsan itu.Sbaliknya dengan menyelamatkan nyawa suatu pribadi samalah hanlnya dengan meneyelamatkan seluruh umat.Kutukan apakah yang lebih kearas terhadap dendam dan pembunuhan pribadi demikian?37

Sifat ramah menjadi ciri utama orang beriman. Rasulullah Saw., bersabda:

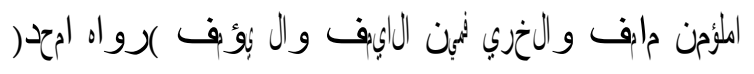

Orang yang beriman adalah orang yang ramah.Tidak ada baiknya orang yang tidak ramah dan tidak pula diramahi. (HR. Ahmad). 
JISA: Jurnal Ilmiah Sosiologi Agama Prodi Sosiologi Agama Fakultas IImu Sosial UIN SU Medan

Vol.1, No.2, Oktober Tahun 2018

${ }^{36}$ Abdullah Yusuf Ali, The Holy Qura"ean (New York: Amman Corporation, 199) Kontak 1480

${ }^{37}$ Abdullah Yusuf Ali, Op.cit., komentar 737. 
JISA: Jurnal Ilmiah Sosiologi Agama

Prodi Sosiologi Agama Fakultas IImu Sosial UIN SU Medan

Vol.1, No.2, Oktober Tahun 2018

Allah mengingatkan bahwa sikap kasar dan bengis akan membuat orang akan enyah dari sekitarnya sebagaimana fiman-Nya:

Maka disebabkan rahmat dari Allah lah akan berlaku lemah terhadap mereka, sekiranya bersikap keras lagi berhati kasar tentulah mereka menjauh dari sekelilingnya. Karena itu maafkanlah mereka mohonlah ampun bagi mereka dan bermusyawarahlah mereka dalam urusan itu.Kemudian apabila kamu telah membulatkan tekad maka bertawakkallah kepada Allah. Sesungguhnya Allah menyukai orang-orang yang bertawakkal (Q.S. 3/Ali-Imran : 159).

Apabila ada orang yang melakukan kekerasan atau bersikap kasar, atau menakut-nakuti dengan cara yang melanggara etika dan melakukan kekerasan (mufsid), meskipun bernama Islam atau mengatasnamakan Islam maka sesungguhnya ia bukan sedang melaksanakan ajaran Islam, melainkan karena karena pemahamannya yang rigit (kaku) dan simplistik (sempit) sehingga tidak mengerti atau mengianati nilai-nilai kasih sayang yang diajarkan Islam.

\section{Apa Yang Harus Dilakukan Umat}

Melihat demikian tumitnya persoalan terorisme, yang secara tak terelakkan berpapasan dengan hidup mereka, langsung maupun tidak langsung, maka umat Islam harus menyikapinya. Untuk itu umat Islam perlu melakukan beberapa hal baik jangka pendek maupun jangka panjang.

Dalam jangka pendek umat Islam perlu melakukan lima hal. Pertama, menolak dan melawan tindakan terorisme karena bertentangan dengan ajaran agama Islam, sebagaimana telah dijelaskan di muka.

Kedua, menolak segala tuduhan dan upaya yang ingin memojokkan umat Islam dengan menggunakan image terorisme.

Ketiga, menunjukkan pada masyarakat dunia bahwa-melalui kata, tulisan, dan perbuatan, bahwa umat Islam tidak setuju dan tidak terlibat dalam tindakantindakan teroris.

Keempat, pada saat yang sama umat Islam perlu menolak segala macam ajakan—oleh siapapun—untuk bergabung dengan kelompok-kelompok yang ingin melakukan kekerasan, menimbulkan ketakutan dan menyudutkan pihak lain, dengan alasan bahwa perbuatan tersebut sebagai pesan agama. Sebab hal itu bukan dari agama dan bahkan bertentangan dengan nilai-nilai yang diajarkan Islam tentang kemanusiaan, kasih sayang, dan kelembutan.

Kelima, dalam melawan dan menumpas terorisme hendaklah didasarkan pada sikap otonom, (the duty, panggilan jiwa dan rasa berkewajiban) secara objektif serta berdasarkan petunjuk Islam bahwa tindakan semacam itu harus 
dilawan dan dicegah karena tidak sesuai dengan ajaran Islam. Bukan karena pengaruh orang atau pihak lain yang hendak mendiktekan kehendaknya. Bukan pula karena sikap rasa rendah diri (imperiority) kita terhadap pihak lain.

Sedangkan dalam jangka panjang umat Islam perlu melakukan lima hal pula. Pertama, melakukan kajian secara mendalam terhadap berbagai penyebab seseorang atau kelompok tertentu melakukan kekerasan, menyulut ketakutan, dan bahkan pemboman, baik dari sudut ketimpangan ekonomi, ketidakadilan kehidupan, stereotipe beragama, dan faktor-faktor lainnya .

Kedua, meningkatkan pemahaman yang lebih humanis, rasional, dan moderat kalangan umat Islam terhadap agamanya, agar tidak terjebak pada paham yang menyulut garis dan sikap keras (tanpa dasar) dalam menegakkan ajaran Islam.

Ketiga, meamahami ayat-ayat Al-Qur'ân dan al-Hadîs sesuai semangat dan praktek yang dilakukan Rasulullah serta para khalifah

yang 'arif bijaksana, bahwa Islam merupakan penyelamat dan rahmat bagi seluruh manusia dan kemanusiaan.

Keempat, Merekonstruksi kajian dan sikap umat mengenai penegakan amar ma'ruf nahi munkar, terutama menyangkut kriteria absah atau tidaknya suatu perbuatan yang diyakini agamis, yaitu niat atau motivasi melakukan suatu perbuatan atau tindakan, kayfiyat atau metode dan caranya, serta ghâyah atau tujuannya. Sebab suatu tindakan, apapun bentuknya, bersifat religius atau tidak, keabsahannya dapat dikukur dan diseleksi menurut kriteria itu.

Kelima, semua pemimpin, cendekiawan, dan ulama, hendaknya dapat melakukan pemberdayaan umat secara sistematis dan serius, serta penuh keteladanan, agar segenap umat Islam dapat menampilkan citra Islam yang kuat dan bermartabat.Wa Allohu A'lamu bi al-Shawab.

\section{Daftar Pustaka}

Akbar S. Ahmed, Postmodernisme and Islam: Predicement and Promise, diterjemahkan ke bahasa Indonesia Posmodernisme: Bahaya dan Harapan bagi Islam, Bandung: Mizan, 1993.

James S. Piscatoriy, Islam in the Political Process, Cambridge:

Cambridge University Press, 1983.

Bruce Lawrence, Defenders, of God:The Fundamentalist Revolt Against the Modern Age, New York: I.B. Tauris, 1990.

Fazluh Rahman, Islam and Modernity: Transformational of an Intellectual Tradition, Chicago: The University of Chicago Press, 1984 